\title{
Compliance Degrees of Endowments Manager to Act No. 41 of 2004 on Endowments
}

\author{
${ }^{1}$ TATA FATHURAHMAN, ${ }^{2}$ AYI SOBARNA \\ ${ }^{1}$ Fakultas Hukum Unisba, ${ }^{2}$ Fakultas Tarbiyah dan Keguruan Unisba \\ email: ${ }^{1}$ tata_fathurrohman@yahoo.co.id
}

\begin{abstract}
Some attractive types of endowment (waqaf) today are progressing on the ground, in form of cash, shares, securities, and copyright. Therefore, endowments can be expected to become the backbone of prosperity in Indonesia. However, as long as these endowments are failed to be optimized and well managed by the incapability of some endowment managers to comply with the Act No. 41 of 2004, there will be many cases occurred against the management of endowments. Endowments Pro ' 99 Bandung is one of the few productive endowments manager which develops very fast. The question raises regarding the performance of endowments management will be to what extent of a degree are these endowment managers compliance with the Act No. 41 of 2004 on endowments? This research was conducted through a descriptive study of the documents owned Wakaf Pro'99 Bandung relevant to pledge, witnesses, and the management of endowments property. The study was conducted by administering questionnaires to endowments manager concerned. by using this method, it is concluded that the Waqf Pro'99 Bandung is in complying with the provisions relating to pledge endowments and gain very high compliance category. Similarly, it is also in complying with the provisions relating to witnesses.
\end{abstract}

Keywords: pledge, witness, wealth management endowments

\section{Introduction}

Attractive types of endowments are now experiencing the addition on the ground, into the money stock, securities, and copyright. Utilization of endowments has also expanded, not only for mosques, Islamic schools, shops, factories and soon, but also for greater purposes. Therefore, expectation for the endowments in Indonesia today has evolved from a provider of worship to become an instrument in poverty alleviation. This is particularly important if a notices directed into at least two things. First, poverty is caused by some factors such as loss of business and a lack of creativity, lack of education and skills, lack of capital or land, and other factors such as old age, sickness, and disability (Ibrahim et al. In the Pulpit: Journal of Social and Development, Vol. 2. No. 1 [June, 2016]). There is no ineffectiveness of priority programs of poverty reduction. Second, according to Sanadjihitu et al. (Pulpit:
Social and Development Journal, Vol. 31, No. 2 [December, 2015]), poverty reduction programs that are integrated in the Medium Term Development Plan/ Long still has not been able to reduce poverty effectively and touched on the basic needs of society, both in the long term as well as medium.

According to Djunaedi (2013), endowments can be expected to be the backbone of prosperity in Indonesia. This expectation considered realistic, especially for at least things: first, the emergence of the middle class (middle class), which is the people with the consumption level of $\$ 2-\$ 20$ per day with the number increased from 1.6 million in 2004 to 50 million people in 2011 (http://puoltrindonesia.com); second, the emergence of philanthropic (derived from the Greek "philein", love, and "Anthropos', man). They are a group of high class who choose to love our fellow human beings in the form of giving charity of money, time, and energy to

Received: August 31, 2016, Revision: November 2, 2016, Accepted: December 19, 2016

Print ISSN: 0215-8175; Online ISSN: 2303-2499. Copyright@2016. Published by Pusat Penerbitan Universitas (P2U) LPPM Unisba Accredited by DIKTI. SK Kemendikbud, No.040/P/2014, valid 18-02-2014 until 18-02-2019 
others (Http://charlybuchari.web.id).

Potential endowments in Indonesia reached 120 trillion per year. The funds can be used for community development and poverty alleviation at the same time. However, this great potential is untapped. on December 2013, the newly collected endowment amounted to 145 billion. It is caused by several factors, especially the lack of understanding and awareness of endowments (Republika Online, May 14, 2014). SSI society survey showed that $31 \%$ of respondents have not received any information about the endowment. The new $19 \%$ respondents plan to give endowments and $55 \%$ respondents plan to do the same if the level of personal economic is well-established (Sobarna, 2014). In terms of managing endowments, based on the survey in 2013, only $48.28 \%$ of waqaf institutions in Bandung new plan becomes productive endowments manager. The rest were undecided or were not even planning anything (Fathurrahman et al, 2013).

Syafruddin (2013) adds that these endowments are generally not optimize and well managed because there are no institutions to handle it effectively. Endowments are managed partially; many agencies do not have legal endowment and endowment assets that have not been certified. As a result, cases sometimes occured, such as case of abuse of endowments property for personal use or for sale. There is even an endowments property being sued by the heirs of the endowments giver.

To overcome such cases, various of strategies on maximizing the finding and utilization of endowments needs to be done to get the maximum benefit. One strategy is the maximizing of the modernization in the management of endowments (Umar, 2006). Modernization is a process of transformation from a traditional life to a more advanced. (Soekanto, 1993). In recent terminology, the terms of the transformation overlaps with the concept of governance (GCG [GCG]). Implementation of GCG driven by awareness of businesses to run a practical effort that promote the survival of the company, the interests of stakeholders, and avoid the ways that simply creating a temporary profit (National Committee on Governance, 2006). GCG related to trust, both to companies that implement them, as well as on the business climate in a country (Boediono, 2006).

GCG is expected to be applied not only to state companies and regional companies but also companies that raise and manage public funds (National Committee on Governance, 2006). Therefore, endowments manager as a collector and manager of public funds, should also apply GCG.

Endowments Pro ' 99 Bandung is one of the few of the productive endowments manager which develops very fast. Endowments manager who has had this legality has a variety of businesses including a meeting room rental, shops, pharmacies, guesthouse and cemetery. Most of the crops have been distributed to the poor medical expenses and scholarships for child who can't afford go to school from elementary to college level (Irawan, 2014). With these efforts, Endowments Pro ' 99 had total assets of USD 83155 billion (approximately 57\%) of the national cash endowments assets worth IDR. 145.8 billion in December 2013. With this percentage, Wakaf Pro'99 had the highest rank mandate in Indonesia (Republika.co.id downloaded dated May 23, 2014).

The fast performance of endowment management raises the question, to what extent this endowments manager comply with Law No. 41 of 2004 on waqf?. To answer this question, a research is necessary to conduct. That is the reason of why the team proposed a research titled Degree of Compliance Wakaf Pro'99 Bandung to Law No. 41, 2004. Based on the formulation of the problems, the purpose of the study is to determine the degree of compliance Wakaf Pro ' 99 Bandung in terms of governance pledge, witnesses, and the governance of management of endowments.

This research is conducted in both theoretical and practical. Theoretically, this research is useful to add a reference on treasures of endowments. Practically, this research is useful for the management of endowments institutions to determine its position in the context of Law No. 41 of endowments. For other endowment's institutions, this study encourages the implementation of Law No. 41 of 2004 on endowments. For the government, this research is expected to be one of consideration of the development of endowments in the country.

\section{GCG and Implementation of Law No. 41}

Endowments are expected to play an important role in improving the welfare of society, especially in poverty reduction through 
raising funds, productive management, and distribution of benefits. This expectation can be achieved when the institution of endowments comply with legal products that have been issued by the government, in this case the Law No. 41 of 2004 on endowments as part of a policy within the framework of governance creates Good Corporate Governance (GCG). endowments institutions must implement GCG consistently and consequently. GCG should be entrenched in institutional endowments to maintain the confidence of stakeholders. When GCG not applied, the endowments institutions will have difficulties due to the orientation of the corporation in the future, including the institution of endowments, is stakeholder oriented. In the institutional stakeholder endowments consisted of endowments, management, employees, beneficiaries, communities and governments. Therefore, the GCG implementation needs to bedone in the endowments institutions.

Implementation of Law No. 41 of 2004 on the institution of endowments is inconsistent and consequent. The order is expected to create a good relationship between endowments giver, management, employees, donatur, society and government. In addition, it will generate asset management and risk management as supporting business development; the development of quality of Human Resources (HR); job safety creation; environmental management and corporate culture development.

This condition will result in the increased of public confidence, especially candidates to entrust treasure they endowments at the institution. For the government, this condition will also affect the spending policies that are more conducive to the development of waqf. For beneficiaries, this condition will increase a number of benefits and the number of beneficiaries. Similarly, for the management and employees of institutional endowments, those conditions will produce more professional human resources in the field of management of endowments. All of which is feedback on the implementation of Law No. 41 of 2004 on endowments.

\section{Descriptive and mixed methods}

This study does not emphasize the hypothesis that has been formulated earlier but stressed the hypothesis on the developed during the research period. This study does not provide treatment or manipulation of the independent variable but describes a condition as it is based on the parameter. Therefore, this study used a descriptive method of nonexperimental (Syaodih, 2007: 73-74).

This study emphasizes on the operational definition based on the provision of judicial, in this case, the Law No. 41, 2004. Data is converted into a numerical score, then it is given a qualitative interpretation. The validity of the measurement is not done through a series of statistical calculation, but by checking compliance with the law. Data is not taken with random techniques to obtain a representative sample but by selecting the expert to gain a purposive sample. Ekstranus for controlling variable, this study did not use a design but a logical analysis. Similarly, for controlling the bias, this study did not use a special design, but emphasizes to honesty of the researchers.

Based on that descriptions, the research uses the mixed method - a combination of quantitative and qualitative methods (Millan and Schumacher, 2007). Judging from the process, this research has inductive characteristics, based on the special proportions as the survey results and ends at a conclusion which is new knowledge. The object of research (in this case Wakaf Pro '99) is seen as a whole in the context, circumstances, and background intact and interconnected. The study also is humanistic, in order to understand personally the person being investigated. All aspects of social life are deemed valuable and important to understand because of the specific and unique (Suyanto, 2006).

More specifically, this study sought to describe two aspects of governance in an institution of waqf. It is based on the view that a single object can be examined more thoroughly than researching groups many institutions. (Meily in http://meilyneman. wordpress.com accessed on 7 April 2014). That is the reason, this study is called a case study, in particular, the case study organizations (Ardhana in http://ardhana12. wordpress.com accessed on February 11, 2014).

The location of this research took place in Bandung, while the development of endowments organization Pro examined in this study is done in the period between 2011-2013. According to Saud (Saud, 2009), the object in this case of study is eligible and extremely bad (bad to the extreme) or extremely good (both extremes). By 
Table 1

Research Parameter

\begin{tabular}{cccc}
\hline No & $\begin{array}{c}\text { Percentage Availability of } \\
\text { Documents }\end{array}$ & Score & Interpretation \\
\hline 1 & $76 \%-100 \%$ & 4 & Very High Compliance \\
2 & $51 \%-75 \%$ & 3 & High Compliance \\
3 & $26 \%-50 \%$ & 2 & Low Compliance \\
4 & $0 \%-25 \%$ & 1 & Very Low Compliance \\
\hline
\end{tabular}

observing the development of Waqf Pro'99 Bandung, this institution appears to meet the criteria of extremely good.

The case studies used in this study using a longitudinal in-depth examination of the circumstances that serve as a case. This method uses the procedure of collecting data through questionnaires, data analysis, refinement (improvement) and the reporting of results. Result of the analysis of the documented study was using the following parameters:

The above table shows that endowments manager has a complete document and easily accessible in the range $76 \%-100 \%$ obtained a score of 4 which can be interpreted as a very high compliance. Endowments manager has sufficient documentation in the range of $51 \%-75 \%$ with gain score 4 which can be interpreted as a high compliance. Endowments manager has sufficient documentation in the range of $26 \%-50 \%$ with gain score 2 that could be construed as poor adherence. While endowments manager has sufficient documentation in the range of $0 \%-25 \%$ with score 1 shall be construed as compliance is very low.

\section{Results of the research on the avail- ability of documents endowment pledge}

Results of research on the availability of documents endowment pledge illustrated in Table 1.
The table shows that the Waqf Pro' 99 had a score of 4 in the availability of a document certifying that the endowment pledges implemented before Pledge Deed Registrar Officer Endowments. Similarly, in the case of a document certifying that the pledge was attended by at least two witnesses, and in the case of a document certifying that the pledge contained in the deed of pledge endowments.

\section{The results of the availability of the witness documents endowments}

Results of research on the availability of witnesses endowments document illustrated in Table 2.

Table 2 shows that the Waqf Pro'99 has a score of 4 in the availability of a document certifying that the witness is an adult. Similarly, a document certifying that the witness is Muslim. While the availability of documents certifying that the witness dietetic Wakaf Pro ' 99 has a score of 1 . Similarly, a document certifying that the witness is not obstructed legal actions endowments manager has a score of 1 .

\section{Results of Documents endowments}

Research on Availability of Documents endowments illustrated in Table $4 a, 4 b$, and $4 c$.

The table shows that the Waqf Pro'99 has a score of 4 in the availability of

Table 2

\section{Pledge Documents}

\begin{tabular}{llc}
\hline No & $\begin{array}{l}\text { Availability of Documents Required In accordance with Law No. } 41 \text { Year } 2004 \text { on Score } \\
\text { Endowments }\end{array}$ & 4 \\
\hline 1 & $\begin{array}{l}\text { Availability of documents certifying that the Pledge Executed In front of Pledge Deed } \\
\text { Registrar Officer Endowments }\end{array}$ \\
$2 \quad \begin{array}{l}\text { Availability of documents certifying that the Pledge is attended by at least two people } \\
\text { Witness }\end{array}$ & $\begin{array}{l}\text { Availability of documents certifying that the Pledge Pledge of Notarial Deed of } \\
\text { Endowment }\end{array}$ \\
\hline
\end{tabular}


Table 3

Witness Documents

\begin{tabular}{clc}
\hline No & \multicolumn{1}{c}{ Availability of Documents Required In accordance with Law } & Score \\
\hline 1 & Availability of a document stating that Witness Already Adults & 4 \\
2 & Availability of a document stating that Witness Religion Islam & 4 \\
3 & Availability of a document stating that Witness dietetic & 1 \\
4 & Availability of documents certifying that the witness did not Hindered Doing Deeds Law & 1 \\
\hline
\end{tabular}

Table $4 a$

Availability of Document Management of Endowments

\begin{tabular}{clc}
\hline No & \multicolumn{1}{c}{$\begin{array}{c}\text { Availability of Documents Required In accordance with Law } \\
\text { No. 41 Year 2004 on Endowments }\end{array}$} & Score \\
\hline 1 & $\begin{array}{l}\text { Availability of documents that describe the purpose of administering the endowments } \\
2\end{array}$ & $\begin{array}{l}\text { Availability of documents certifying that the endowment will be accompanied two } \\
\text { witnesses }\end{array}$ \\
3 & $\begin{array}{l}\text { Availability of documents certifying that the endowments will Executed After } \\
\text { endowments giver Dies }\end{array}$ & 4 \\
\hline
\end{tabular}

Table 4b

Availability of Document Management of Endowments

\begin{tabular}{clc}
\hline No & \multicolumn{1}{c}{$\begin{array}{c}\text { Availability of Documents Required In accordance with Law } \\
\text { No. } \mathbf{4 1} \text { Year } \mathbf{2 0 0 4} \text { on endowments }\end{array}$} & Score \\
\hline 1 & $\begin{array}{l}\text { Availability of documents certifying that the receiver will act as the attorney } \\
\text { endowments giver }\end{array}$ & 4 \\
2 & $\begin{array}{l}\text { Availability of documents that describe endowments manager keep proof of registration } \\
\text { of endowments }\end{array}$ & 4 \\
3 & $\begin{array}{l}\text { Availability of documents that describe in terms of the transfer function of endowments, } \\
\text { endowments manager sign up again to the Indonesian Endowments Board }\end{array}$ & 4 \\
\hline
\end{tabular}

Table 4c

Availability of Document Management of Endowments

\begin{tabular}{clcc}
\hline No & \multicolumn{1}{c}{$\begin{array}{c}\text { Availability of Documents Required In accordance with Law } \\
\text { No. } \mathbf{4 1} \text { Year 2004 on Endowments }\end{array}$} & Score \\
\hline 1 & $\begin{array}{l}\text { Availability of documents stating that in the event that the transfer function of } \\
\text { endowments, endowment managers to register back to the authorized agency }\end{array}$ & 4 \\
2 & $\begin{array}{l}\text { Availability of documents certifying that the waqf property can not be guaranteed } \\
3\end{array}$ & $\begin{array}{l}\text { Availability of documents certifying that the transfer function of waqf implemented } \\
\text { after obtaining written permission from the Minister of Religious Affairs }\end{array}$ & 3 \\
\hline
\end{tabular}

documents that describe the purpose of administering the endowments. Endowments Pro 99 score of 4 is also in the availability of a document certifying that the endowment will be accompanied by two witnesses. Similarly, in terms of availability document certifying that the endowment will be implemented after endowments giver died Wakaf Pro 99 has a score of 4.

The table shows that the Waqf Pro'99 has a score of 4 in the availability of a document certifying that the receiver will act as the authorized waqf giver. Then, a document certifying that endowments manager keep proof of registration endowments also have a score of 4 . Availability of documents that describe in terms of the transfer function of endowments, endowments manager register back to Indonesian Endowments Board has a score of 4 .

The table shows that the waqf Pro'99 has a score of 4 in the availability of a document certifying that the transfer function of the endowments, endowments manager sign up again to the relevant authorities. Then, the document explains that the endowments property can not be used as collateral 3 . Similarly, the availability of documents that describe in terms of the transfer of the transfer function of endowments performed after obtaining written permission from the Minister of Religious Affairs has a score of 3 . 
Table 4d

Availability of Document Management of Endowments

\begin{tabular}{clc}
\hline No & \multicolumn{1}{c}{$\begin{array}{c}\text { Availability of Documents Required In accordance with Law } \\
\text { No. 41 Year 2004 on Endowments }\end{array}$} & Score \\
\hline 1 & $\begin{array}{l}\text { Availability of documents that describe the quality of endowments property } \\
\text { replacement }\end{array}$ & 3 \\
2 & $\begin{array}{l}\text { Availability of documents certifying that endowments manager manage endowments } \\
\text { property in accordance allotment }\end{array}$ & 3 \\
3 & Availability of documents that describe the dispute settlement mechanism & 4 \\
\hline
\end{tabular}

The table shows that the waqf Pro'99 has a score in the availability of documents that describe the quality of endowments property replacement. Then, in terms of availability of documents stated that endowments manager who manage waqf property in accordance designation has a score of 3 . Similarly, the availability of documents that describe the dispute settlement mechanism has a score.

\section{Discussion of Results of Research on the Implementation of the Pledge Terms of Endowment}

Endowments is a legal act. Therefore, the pledge made by the endowments manager required endowments giver held in front of the Pledge Deed Registrar Endowments Officer. This provision is contained in Article 17 point 1 of Law No. 41 of 2004 on Endowments. Endowments manager should create a document this deed neatly.

The pledge means the promise, contract, agreement, oath, establishment or recognition. Vowed means promise, agree, agree, or swear. The pledge means affirming, binding, confirm, confirmed, acknowledge, or endorse (Endarmoko, 2007). According to the Dictionary, pledge means promise earnest, firm pledge, acknowledging a truth (Compiler Team KBBI, 199).

If it is related to endowments, the meaning of pledge is a sincerely promise or agreement in an endowment promised to admit the truth. Pledge endowments should be attended by two witnesses. After endowments giver expressed endowment pledge to endowments manager in front of Registrars Officers Endowment Deed Pledge (PPAIW), PPAIW pours it in the deed of pledge endowments. This provision is contained in Article 17 point 1 of Law No. 41 of 2004 on Endowments. The presence of these two witnesses must be evidenced by the signature of two witnesses in the official report. Endowments manager news must document this event.

Pledge stated orally and/or in writing and set forth in the deed of pledge endowments by PPAIW. This provision is contained in Article 21 point b Law No. 41, 2004. Not quite pledge endowments only form of greeting. As with debts or purchase, or pledge wedding, endowments must be recorded. This is very useful as a savior in the case of the incident or forgotten. Therefore, Endowments manager should document this endowments deed of the pledge.

The results showed that the Waqf Pro ' 99 had a score of 4 , which means having $76 \%$ $-100 \%$ tidy and easily accessible documents (very high compliance rate) in the availability of a document certifying that the endowment pledges implemented before PPAIW. Similarly, in the case of a document certifying that the pledge was attended by at least two witnesses, and in the case of a document certifying that the pledge contained in the deed of pledge endowments. These scores can be interpreted to mean that in the case of this documentation can be categorized Wakaf Pro'99 have very high levels of compliance.

\section{Discussion The results of the Imple- mentation Provisions of Witness endowments}

According to the Indonesian Thesaurus (Endarmoko, 2007), martyr means witness, audience, and evidence. Testifying means justify, strengthen, and homologate. Witnessing means seeing, descry and watch. Witness means to show, demonstrate and perform. Testimony means witness testimony.

According to the dictionary, the meaning of witnesses who saw or knows itself an event or events; people are asked to be present at an event to know that one day, if necessary, be able to provide information which confirmed that the incident actually took place (Compiler Team KBBI, 19).

Thus, the witness endowments are 
people who see or understand themselves as an endowment pledge that one day, if necessary, the witness can provide information confirming that pledge endowment was actually happening.

The witness must be an adult. It is not valid if the witness was a child. This provision is contained in Article 20 letter an of Law No. 41 Year 2004. Description of this is proven by a copy of identity card or family card. It contains a testimony of the witness at that day where endowments manager should document the information that has been witnessed already that day. It is necessary to avoid future lawsuits.

Conditions of Muslim witnesses listed in Article 20 letter b of Law No. 41 Year 2004. This provision is an implication of the principle that the endowment is part of social Muslims worship. It is not legitimate if it is done by non-Muslim waqf witness. This provision can be proved by the Identity Card. Endowments manager should administer this National Identity Card.

Provision that the witness should be sensible is listed in Article 20 letter c of Law No. 41,2004 . If the maturity of witnesses rests on the age of the data, it is based on the common sense of the statement that the witness is able to think normally. Unauthorized pledge endowment take place if the witness is an adult but his mind is not normal. Data sensible is the data that the witness should be well documented. Dietetic witness testimony can be made by the witness. This statement applies to no other information that indicates that the witness distracted.

Provision that the witness is not obstructed to perform legal acts is listed in Article 20 letter d of Law No. 41 Year 2004. This provision is an implication of the principle that an endowment is a legal act, therefore, the witness endowments when the pledge should not be within the prohibition of legal actions. This prohibition in the form of a letter issued by a court that has a provision remains. So, there must be data to explain that the person concerned is not obstructed legal actions. Information related is in the form of a Certificate of Good behavior of the police. Endowments manager must document a certificate of good conduct of this witness.

The results showed that the Waqf Pro' 99 has a score of 4 , which means having $76 \%$ $-100 \%$ tidy and easily accessible documents (very high compliance rate) in the availability of a document certifying that the witness is an adult. Similarly, a document certifying that the witness is Muslim has a score of 4 , which means a very high level of compliance. While the availability of documents certifying that the witness dietetic Wakaf Pro ' 99 had a score of 1 meaning it has $0 \%-25 \%$ of documents that can be interpreted very low levels of compliance. Similarly, a document certifying that the witness is not obstructed legal actions endowments manager has a score of 1 can be interpreted to have very low levels of compliance.

\section{Discussion of Results of Research on Management of Endowments}

Management means sponsorship, organizing, and structuring. Management derived from the word governance means managing, lap, implement, nurture, manage, control, operate, administer, operate, administer, govern, dominate, and support (Endarmoko, 2007).

According to Indonesian dictionary, managing means the process of doing certain activities by moving the power of others; a process that helps to formulate policies and objectives of the organization; a process that provides oversight on all matters involved in the implementation of the policy and goal attainment (Compiler Team KBBI, 199).

Based on with this understanding, the management of endowments means the process of conducting activities by formulating policies and objectives endowments manager to provide oversight on all involved to achieve the objectives of endowments.

Articles 22 and 23 of Law No. 41 of 2004 outlined that the purpose and function of management of waqf which are to: (a) construct the facilities and religious activities; (b) build facilities and activities and health education; (c) assist the poor abandoned their children, orphans, give scholarships; (d) make a progress and economic improvement of the people; and/or (e) Other common welfare advances that are not on contrary to the sharia and legislation. The purpose and function of this should be documented in endowments manager neatly.

Article 24 of Law No. 41 of 2004 outlined that if the endowment will be done in both oral and writing only when witnessed by at least two (2) witnesses. Testimony and witness identification should be documented with a neat stretcher. 
If the endowment is done with a will, endowments will be implemented by the recipient after the relevant providers die. This provision constituted in Article 26 of Law No. 41 of 2004 . The implications of this provision is that the endowments manager must ensure that providers will have died.

The results showed that the Waqf Pro'99 has a score of 4 , which means having $76 \%$ $-100 \%$ tidy and easily accessible documents (very high compliance rate) in the availability of documents that describe the purpose of administering the endowments. Scores can be interpreted that this endowments manager has a very high level of compliance. Wakaf Pro 99 also has a score of 4 , which means having $76 \%-100 \%$ tidy and easily accessible documents (very high compliance rate) in the availability of a document certifying that the endowment will be accompanied by two witnesses. Similarly, in terms availability document certifying that the endowment will be implemented after endowments giver died Wakaf Pro 99 has a score of 4, which means having $76 \%-100 \%$ tidy and easily accessible documents (very high level of compliance).

If the endowment is done with a will, the receiver will act as a power of endowments giver. This provision constituted in Article 26 of Law No. 41 of 2004. The implication of this provision is endowments giver should document the file that contains the identity of endowment giver's power. Endowments manager keep proof of registration endowments property delivered by endowments deed registrar pledge. Article 35 of Law No. 41 of 2004 on Endowments.

Article 36 In the case of endowments property exchanged or amended designation endowments manager through endowments deed registrar pledge reapplying to the Indonesian Endowments Board on endowments property is exchanged or amended designation is in accordance with the applicable provisions in the procedure of registration of endowments property.

Article 40 (1) and (2) stated that there is a document which states the treasures that have been endowment which will not be used as collateral, confiscated, granted, on sale, inherited, exchanged, or transferred in the form of transfer of any other rights excluded if endowments property of endowment has been used for public purposes in accordance with the general plan layout under the provisions of the legislation in force and does not conflict against sharia.
Article 40 (2) is in the case of the implementation of the transfer function of endowments, conducted after obtaining written permission from the Minister with the approval of Indonesian Endowments Board.

The results showed that the Waqf Pro'99 has a score of 4, which means having $76 \%-100 \%$ tidy and easily accessible documents (very high compliance rate) in the availability of a document certifying that the transfer function of the endowments, endowments sign up again to the relevant authorities. Then, the document explains that the endowments property can not be used as collateral 3 (high level of adherence). Similarly, the availability of documents that describe in terms of the transfer of the transfer function of endowments performed after obtaining written permission from the Minister of Religious Affairs has a score of 3 .

Article 40 (3) stated that The Treasure of the endowment that has changed its status for exemption referred to in paragraph (1) shall be exchanged with the wealth of benefits and the exchange rate at. least equal to the original endowments property. Article 42 states that endowments must manage and develop endowments property in accordance with the objectives, functions, and purposes.

Endowments dispute is settled through deliberations to reach consensus. If the meeting was unable to reach an agreement, the dispute is resolved through mediation, arbitration or court. Article 62 of Law No. 41 of 2004 on Endowments.

The results showed that the Waqf Pro'99 has a score of 3 in the availability of documents that describe the quality of endowments property replacement. Then, in terms of availability of documents stating that endowments manager manage endowments property in accordance designation has a score of 3 , while the availability of documents that describe the dispute settlement mechanism, endowments manager it has a score of 4 , which means having 76\%-100\% tidy and easily accessible documents (level of compliance very high).

\section{Conclusions}

Based on the discussion of the research results in Chapter IV, it can be concluded that the Waqf Pro'99 Bandung in complying with the provisions of witnesses, only half categorized compliance are high, while the other half very low compliance category. Very 
high level of compliance was contributed by the availability of a document certifying that the witness is an adult and that the witness is Muslim. While the very low level of compliance was contributed by the unwillingness of the document certifying that the witness reasonable and that the witness was not being hindered legal actions.

Based on the discussion of the research results in Chapter IV, it can be concluded that the Waqf Pro'99 Bandung to comply with provisions of the management of waqf property category have very high compliance and high compliance. Category compliance are high donated by the availability of documents that describe the purpose of administering the endowment, availability of documents stating that endowment will accompanied by two witnesses, the availability of a document certifying that the endowment will be implemented after endowments giver died, the availability of a document certifying that the receiver will act as the attorney endowments giver, availability of documents stating that endowments manager keep proof of registration, availability of documents stating that in the event that the transfer function of endowments, endowments manager register back to BWI, and the availability of documents that describe the dispute settlement mechanism endowments.

While in providing a document certifying that the endowments property can not be used as collateral, Endowments Pro'99 have high compliance. Similarly to provide a document certifying that the transfer function of endowments implemented after obtaining written permission from the Minister of Religion endowments manager has high compliance. The next high compliance category of Waqf Pro'99 obtained in terms of the availability of documents that describe the quality of endowments property replacement and availability of documents stating that endowments manager manage waqf property with appropriate designation.

\section{References}

Djunaedi, Achmad (2009). Strategi Pengembangan Wakaf Tunai, Direktorat Pemberdayaan Wakaf Direktorat Jenderal Bimbingan Masyarakat Islam Departemen Agama RI., Jakarta.

Djunaedi, Achmad (2009). Pedoman Pengelolaan Wakaf Tunai, Direktorat Pemberdayaan Wakaf Direktorat Jenderal
Bimbingan Masyarakat Islam Departemen Agama RI., Jakarta.

Endarmoko, Eko (2007). Tesaurus Bahasa Indonesia, Balai Pustaka, Jakarta.

Fathurrohman, Tata, dkk., 2013. Profil Institusi Wakaf di Kota Bandung sebagai ObjekPembinaan Wakaf Produktif, (Belum Diterbitkan), Lembaga Penelitian dan Pengabdian kepada Masyarakat Universitas Islam Bandung.

Ibrahim dkk. dalam Mimbar: Jurnal Sosial dan Pembangunan, Vol 2. No. 1 (Juni, 2016) Pusat Penerbitan Universitas (P2U) Lembaga Penelitian dan Pengabdian kepada Masyarakat (LPPM) Universitas Islam Bandung.

Mubarok, Jaih (2009), Wakaf Produktif, Direktorat Pemberdayaan Wakaf. Direktorat Jenderal Bimbingan Masyarakat Islam Departemen Agama RI., Jakarta.

Peraturan Presiden Republik Indonesia. Nomor 13 Thn. 2009 tentang Koordinasi Penanggulangan Kemiskinan.

KNCG (Komite Nasional Kebijakan Corporate Governance) (2006). Pedoman Good Corporate Governance, Bank Indonesia, Jakarta.

Masudi, Masdar Farid (2010). Syarah Konstitusi UUD 1945 Perspektif Islam, Swa Media Research dan Perhimpunan Pengembangan Pesantren dan Masyarakat (P3M), Jakarta.

Meily dalam http://meilyneman.wordpress. com diakses pada 7 April 2014.

Millan, James H. Mc. dan Sally Schumacher (2007). Research in Education: A Conceptual Introduction, Longman, London.

Sanadjihitu dkk. (Mimbar: Jurnal Sosial dan Pembangunan, Vol. 31, No. 2 (Desember, 2015), Pusat Penerbitan Universitas (P2U) Lembaga Penelitian dan Pengabdian kepada Masyarakat (LPPM) Universitas Islam Bandung.

Saud, Udin Saefuddin (2009). Metodologi Penelitian, Modul, Sekolah Pascasarjana Universitas Pendidikan Indonesia, Bandung.

Suhardin, Yohanes, Peranan Negara dan Hukum dalam Memberantas Kemiskinan dengan Mewujudkan Kesejahteraan Umum, dalam Jurnal Hukum dan Pembangunan Tahun ke-40 No. 3 Juli 2010, Badan Penerbit Fakultas Hukum Universitas Indonesia, Jakarta.

Suyanto, Bagong dan Sutinah (2006). Metode Penelitian Sosial, Kencana, Jakarta.

Tim Penyusun (1993). Kamus Besar Bahasa Indonesia, Balai Pustaka, Jakarta. 
MiMBAR, Vol. 32, No. $2^{\text {nd }}$ (December, 2016), pp.446-455

Wawancara dengan Direktur Wakaf Pro'99 Bandung, Asep Irawan tanggal 8 April 2014).

Undang undang No. 11 Thn. 2005 Tentang Pelaksanaan kovenan Internasional tentang Hak-hak Ekonomi, Sosial, dan Budaya.

Undang-undang Republik Indonesia Nomor 42 Tahun 2006 tentang Wakaf. 